\title{
アフリカ豚コレラの歴史とリスク分析
}

\author{
小澤義博*
}

OIE 名誉顧問

\section{African Swine Fever : Historical Review and Risk Analysis}

\author{
Yoshihiro OZAWA* \\ OIE Honorary Adviser
}

\begin{abstract}
Summary
African swine fever (ASF) outbreaks which originated from Africa were chronologically reviewed with emphasis on how they were spread to Europe and the other continents. In 2007, ASF suddenly appeared in the countries in the east end of the Black Sea including Russia. As the disease has been well established in Russia, the strategies for ASF should be planned to fight against its risks from two continents, Africa and Russia (Eurasia). It will be extremely difficult to prevent the entry of ASF-infected wildlife from the countries that share land borders. Special attention should be paid to the fact that more than $50 \%$ of the swine population of the world is located in China. Feasibility studies should be performed to separate them from infected boars and feral swine by reinforcing barriers such as the Great Wall of China by adding wire walls and new electro-devices.
\end{abstract}

\section{1） アフリカ豚コレラウィルスの特性}

アフリカ豚コレラ (ASF) は昔からアフリカ在来の warthohog (イボイノシシ), wild boar (イノシシ), soft ticks (ダニの一種) に不顕潜感染を続けてきた Asfivirusに よる豚の病気である。アジアや欧米でよく知られている 「豚コレラ」とは全く異なるウィルスによっておこる病気 である。アフリカに白人が豚を持ち込むまでは ASF ウィ ルスの存在すら知られていなかった。ASFウィルスは 2 本錯の DNA ウイルスで, 感染した豚や野生動物の血液や 組織や肉製品, ダニなどの中で長期間生存できる。またア フリカにおける感受性を有する野生動物やダニは, ASF に感染してもなんら症状を示さず生存することが知られて いる。豚が ASF に感染すると高い死亡率を示す急性のウィ ルス病であるが, 時として慢性経過を示すASF ウィルス の存在することが知られている ${ }^{1)}$ 。

ASF ウィルスは自然環境に強く, 4 度 Cに保存された血 液中で約 1 年半生存することがある。感染した豚の排泄物 中でも室温で約 1 年半生存できる。また豚舎の中では約一

連絡先 : 小澤義博*

干158-0094 東京都世田谷区玉川 1-15-2-3404

Tel \& Fax : 03-6320-7815
ケ月生存できる。骨付き肉では約 150 日間, 塩付け乾燥八 ムで 140 日間, 凍結肉では数年間生存できる。ASF ウィ ルスには多くの遺伝子型が存在するが，イベリア半島に広 がったウィルスは 1 型で比較的に弱毒のウィルスである が, 2007 年に黒海地方に広がったウィルスは 2 型で急性 の経過をたどる゙2。

ASF ウィルスは人には感染しないが，感染した豚には 色々抗体が出来る。しかし中和抗体ができにくいので弱毒 生ワクチンの開発が試みられてきたが，未だに実用化され ていない。ASFの治療薬は存在しない。従って今のとこ ろ ASFのコントロールや撲滅には, 感染国の豚やイノシ シなどの感受性のある動物の殺処分に頼るしかない。しか し特定の野生動物の完全な淘汰は極めて難しく, ロシアは 今のところ国内のイノシシのコントロール/淘汰には自信 がないようである。

\section{2） アフリカにおける ASF の歴史 （養豚失敗の歴史）}

アフリカへの入植者（白人）が増えると, 各地で養豚が 試みられたが，いずれも失敗の繰り返しであった。それは アフリカ中南部には感受性をもつ野生のイボイノシシやダ ニが ASF ウィルスに不顕性感染して存在していたためで, 
それを知らずに始めた養豚はすべからく失敗の繰り返しで あった。従ってアフリカにおける畜産は, 主として反炰獣 (牛や羊, 山羊など) の放牧が主体であった。

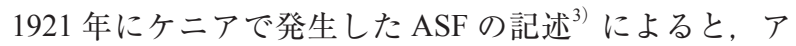
フリカにおける ASF の存在は, 少なくとも 1907 年頃から 知られていて, アフリカに住んだことのある欧米の入植者 の間では「アフリカで養豚を試みると, 必ず失敗して全滅 する」といわれてきた。

近年, アフリカにおける植民地制度の衰退が続き, 各地 で独立運動が高まると多くの白人が土地を売ってアフリカ 以外の国に移住するようになった。それに伴いアフリカ諸 国の獣医行政レベルの衰退が続き, それを補うために海外 からの技術支援が増えるようになった。1980年代に入る とアフリカの牛疫撲滅運動 (PARC) が始まり, OAU-IBAR に対する技術支援が強化され, FAO, EEC, ILRI などの国 際機関の技術援助が強化された。一方, 独立したアフリカ 諸国の消費者も新たな蛋白資源として, 豚肉の生産に注目 するようになり，アフリカ諸国の ASF の発生が次第に増 えてきた。近年（2009～2011 年）アフリカではASF の発 生は26 ケ国で報告されるようになっだ)。

一方, 中国のアフリカ諸国に対する援助は大規模で, 資 源の開発やその輸出, 学校や橋や道路などのインフラの強 化に力が注がれ, 数多くの技術者や労働者が中国からアフ リカに送り込まれている。アフリカに住む外国人の数が増 えると, 再び反炰動物以外の豚肉や鶏肉の需要が高まり, 次第に隔離した生産技術にも力を注ぐようになり, 養豚技 術の改善も一部で見られるようになった。しかしアフリカ でASFの発生がふえると, ASFに污染した豚肉や臓器の 加工製品の流通が増え, 人や船舶や航空機の国際的移動に より, 污染した豚由来の製品が再びアフリカ外に流出する リスクが高まってきている。

\section{3） ASF のアフリカ大陸外への侵出の歴史}

ASF はアフリカに移住した欧米の入植者の間ではよく 知られてきた病気である。しかしアフリカ諸国の独立が進 み, 西欧からの入植者のアフリカ外への脱出が急激に進む と, アフリカ諸国の獣医行政力の低下が各地で見られるよ うになった。近年アフリカでは, 白人のアフリカ脱出が続 き, 彼らに代わって, 中国その他のアジア系の国々からの 援助が急激に増え, 新たな外国人による豚肉の需用が増え, その結果アフリカ諸国で再び ASF のリスクが高まりつつ ある。

今日までに ASFがアフリカ大陸外に進出した歴史を 辿ってみると, ポルトガル（1957 年と 1960 年）とマダガ スカル（1998 年）とジョージア（2007 年）の 3 回だけで ある。その他は侵入先から更に広がったケースである。
ASF のアフリカ脱出は下記の 3 回のみである。

\section{第 1 回目 : アンゴラから欧州に侵入}

1957：Portugal：アンゴラからリスボンに到着した航空機 の残飯から ASF が発生したが淘汰された。

1960〜 1994 : Portugal（アンゴラから帰還した兵士が持ち 帰った豚肉製品が原因)

1960〜 Spain：ポルトガルから侵入し，1995 年に撲滅さ れた。

1964〜1967 : France (スペインから侵入)

1967〜 1969: 1taly (隣国から侵入)

1971 年; Cuba（カストロ政権に対するテロ攻撃！約 500,000 頭を殺処分)

\section{イベリア半島から欧州および中南米へ5)}

1974 France (Eradicated)

1978*〜Sardinia（Italy）に米艦の寄港により侵入し今日に 至る。

1978*〜1979 : Malta に米艦の寄港により侵入（FAO/EECに より淘汰)

1978*〜1980 : Dominican Rep. (Spain からの航空機の残飯 により侵入)

1978*〜1984 : Haiti. (Dominican Rep の国境から侵入)

1978*〜1981 : Brazil（Rio de Janeiro 着の航空機の残飯によ り侵入)

1979 1980 : Sao Tome \& Principe（Angola からの輸入肉）

1980：Cuba（from Haiti？）淘汰された。

1985 Belgium（(限定的発生)

1986 Netherlands（限定的発生）

第2回目: 1998年 東部アフリカからマダガスカルに侵入6) 東部アフリカ（恐らくモザンビーク）からの船でマダガ スカルに持ち达まれたと言われている。マダガスカルには アジア系の住民が多く小規模の養豚は現金を得るための良 いビジネスであったが, ASFの侵入により大打撃をうけた。 しかし今のところ生き残っている豚の数は少ないので, マ ダガスカルから海外に広がるリスクはネグリジブルに近 い。（しかしイノシシやダニに残っている）近年, マダガ スカルに対する中国，韓国や日本の投資が増えており，今 後の ASF の発生状況に注意する必要がある。

第 3 回目 : アフリカ東部から黒海沿岸（ユーラシア, ロシ ア等) へ侵入 ${ }^{7)}$

第 3 回目の流出はアフリカ東部 (恐らくモザンビーク) から黒海沿岸のジョージアの Poti に入港した船が残した 大量の残飯を熱処理せずに豚に与えることよって広がった といわれている。黒海沿岸のコーカサス地域からロシアや 東欧にまで広がって今日に至っている。

2007〜 Georgia（黒海の Poti に寄港した船の残飯が原因）

2007 Armenia 


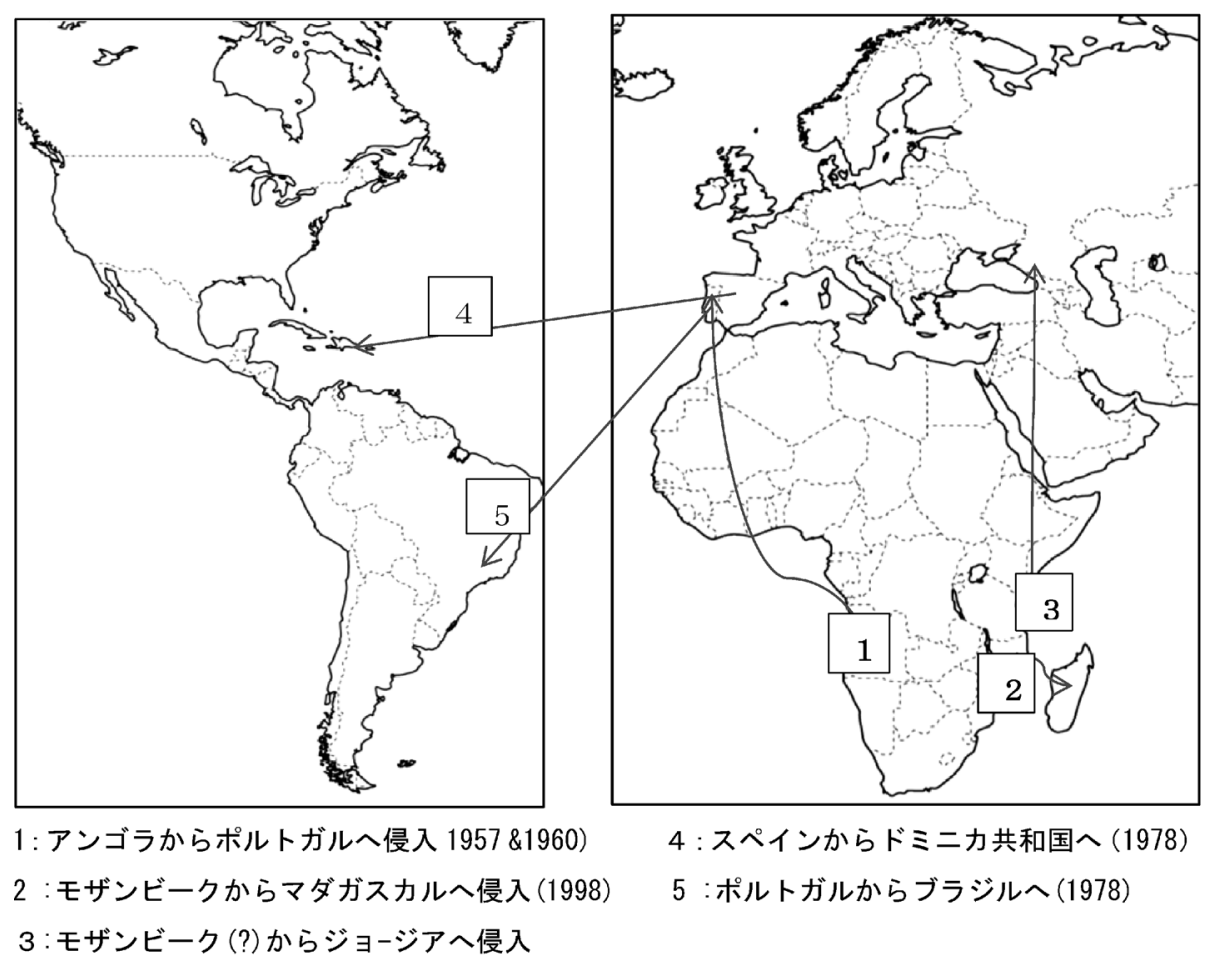

図 1 ASF のアフリカ大陸外への侵出

2007 Russia

2008 Azerbaijan,

2009〜 Iran（感染したイノシシの侵入による）

2012 Ukraine,

2013 Belarus

2014〜 Lithuania, Poland（感染したイノシシの侵入による）

現在, ロシア・東欧における ASFの広大は主として野 生豚（イノシシ）の移動による。夏季に入るとイノシシの 活動範囲がロシア東部にも広がる可能性が高まるものと考 えられる。

今日までにASF がアフリカ大陸から侵出した歴史をま とめてみると, 図 1 に示す如くアフリカ大陸からの侵出は 3 回のみである。第 1 回目は 1960 年代にポルトガルとス ペインに発生し, 1978 年にポルトガルやスペインから西 欧や地中海地域やカリブ海やブラジルにまで拡がった。今 日ではイタリアのサルデニア島にだけ残っている。第 2 回 目は1998 年にアフリカ東部（恐らくモザンビーク）から マダカスカルに侵入し今日に至っている。第 3 回目は 2007 年にアフリカ東部から黒海沿岸のジョージアに侵入 し，ロシア西部一帯に広がり東欧にまで広がりつつある。 今後はロシアの ASF の動きが欧州諸国やアジア諸国の養 豚関係者に大きな劦威となっていくものと思われる。

筆者が FAO の衛生課長として ASF の撲滅運動に関与し
たのは, 地中海地域と中南米の ASF の撲滅運動であった。 マルタ, ドミニカ共和国，ハイチ，ブラジルの清浄化には 成功したが, イタリア (サルデニア島) の養豚業にマフィ アが関与していたため, FAO も EEC も最後まで援助の手 が出せなかった。2012 年になってマフィア問題が解決し たのか, EUによる ASF の撲滅運動が目下進行中である。 筆者が視察旅行中に最も印象的であったのは, 南米のカラ カスの空港で見た光景であった。その日はたまたま検疫の 特別強化の日で，欧州からのすべての旅行者の荷物を開い て検査したところ，禁止されていた豚肉製品が押収され， 四畳半程の部屋にぎっしり山積みされていたのを見て，検 疫犬の必要性を痛感した。

\section{4） 今後の問題}

かつては海に囲まれたアフリカ大陸だけが ASF の感染 源であったが，ASFがロシアに侵入してからは第二の ASF の輸出センターが確立されたことになる。従って世 界の ASF 対策は 2 面対策に切り替えなければならない。 また ASFの侵入リスクは国境が陸続きの場合と, 河や湖 や海によって隔離されている場合では大きな差がある。陸 続きの国境の場合は, 全ての感染動物や昆虫の侵入を防止 せねばならなので，完全に防ぐことは極めて難しくなる。 そのうえ一旦イノシシなどの野生動物が ASF に感染して 
表 1 世界の養豚頭数の上位 10 ケ国（USDA : 2014 年）

\begin{tabular}{|c|c|c|c|c|c|}
\hline \multicolumn{3}{|c|}{ 順位/国名/頭数（×1000 頭） } & \multicolumn{3}{|c|}{ 順位/国名/頭数（×1000 頭） } \\
\hline 1 & 中国 & 729,105 & 6 & カナダ & 27,300 \\
\hline 2 & $\mathrm{EU}^{2,7)}$ & 257,150 & 7 & 日本 & 17,210 \\
\hline 3 & アメリカ & 113,206 & 8 & メキシコ & 16,750 \\
\hline 4 & ブラジル & 38,470 & 9 & 韓国 & 15,500 \\
\hline 5 & ロシア & 38,290 & 10 & ウクライナ & 9,580 \\
\hline
\end{tabular}

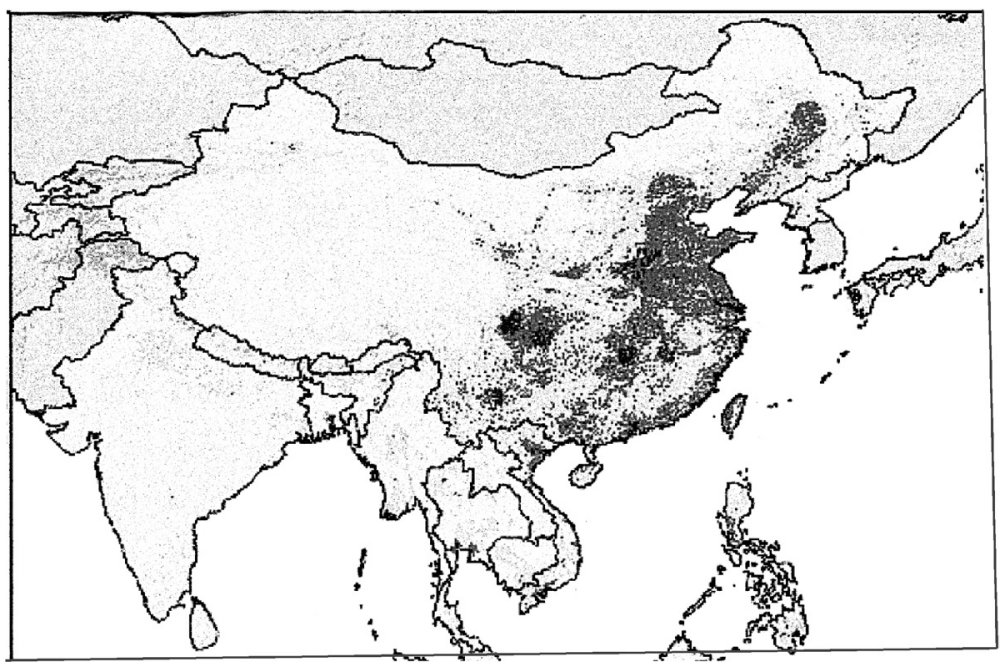

図 2 中国における養豚の密度 (FAO : Pig density map 2005)

広がってしまうと, 感染した野生動物の完全な淘汰は極め て難しくなり, 特にロシアのごとく広大な国の野生動物 （イノシシ）を完全に淘汰することは不可能である。従っ てロシア周辺の ASF 感染国の数は今後も増え続けるであ ろう。

表 1 に示してあるようにユーラシア大陸には, 中国の如 く世界の半数以上の豚を生産している養豚大国がロシアと 国境を接している。現状では中国は南からからも北からも ASF が侵入するリスクが高まってきている。特に北側は 陸続きの長い国境があるので, この新たな難題を解決する ためには, 出来るだけ早く国際機関を含めて, 長期的な計 画を作成る必要がある。少し大げさに言えば，世界の養豚 業を守るためには, 万里の頂上のごとき少し奇抜な防壁の 再構築が必要になるかもしれない。

\section{5）ASFのリスク分析とその対策}

アフリカ大陸の ASF はこれからも増加する傾向にある。 その理由としてはアフリカ中南部の多くの国々（回教国を 除く）では, 蛋白資源としての豚肉の需要が次第に高まり
つつある。また中国その他のアジアの国々の技術・開発援 助が急増しており, アフリカにおけるアジア人の人口が増 加している。従って豚肉の需要も次第に増えてきている。 またアジア人の多くは, 帰国時に土産品して加工した豚肉 やその製品の需要が高いので, ASF がアジアへ流出する リスクは次第に高まっていくであろう。

ユーラシア大陸に ASF の新たなセンターが確立された 今, 世界の ASF 対策は 2 面対策に切変える必要がある。 日本を含むアジア諸国にとっては, 後者のロシアとその周 辺国の ASF に対する長期計画を真剣に検討し, 必要な対 策を講じて行く必要がある。アフリカセンターに対する対 策は嘗ての西欧諸国のとってきた対策を欧州, アメリカ, アジア諸国の問題として強化して行けばよい。しかしロシ アを中心とした第二の ASF センターに対応するためには, 新たな対応策の構築を余儀なくされる。特に考慮すべき点 は，ユーラシア大陸には陸続きの国が多く，陸続きの国境 を自由に通過することのできるイノシシなどの野生動物が 多いことである。この新たな問題の解決策なくしてユーラ シア大陸の ASF の問題解決は望めない。幸い日本は海で 
ユーラシア大陸から隔離されているが, 安心は禁物である。 これからは狂犬病の森林型と同じく, ASF の野生動物対 策を強化してゆくべき時にきている。

\section{6） ASF に感染した動物とその危険物の輸入禁止}

ASF の歴史から言えることは, 感染した動物（豚, イ ノシシ及びダニ等）が陸つづきで国境を越えて広がるリス クと, 感染した豚やイノシシの肉, 臟器とその加工食品が 車，列車，飛行機，船などを経由して国境を越えて広がる リスクに分けることが出来る。その危険物を品目別に分け てみると

1） ASF ウィルスに感受性を有する動物（豚，イノシシ, イボイノシシなど）とダニ (Ornithodoros) の ASF 感 染国及びその可能性のある国々からの輸入。

2）感染国の豚やイノシシの肉や臓器及びそれらの加工品 (食品や土産物)。

3）豚やイノシシの肉や臟物を使って作られた食品や弁当 の持ち込み。

4) 車，バス，列車，船舶，航空機などからでた残飯。 などに分けることが出来る。これらの危険因子の侵入を防 止するためには，次の対策がひつようとなる。

\section{イ）感染した動物の移動の監視（国境が地続きの場合）}

ASF に感染した動物（豚, 野生動物やダニ）の移動に よるリスクは, アフリカやロシアや東欧諸国のように陸で 接した国々の間で起こり，そのリスクは非常に高い。

特に野生動物の移動によるリスクは極めて高く, これを 防ぐためには万里の長城や韓国の 38 度線の干渉地帯やべ ルリンの壁のように，感染動物や車や鉄道による污染物の 移動を完全に遮断するしかない。それでも野生動物やダニ のような昆虫の移動を完全に防ぐことは難しい。(ASFウィ ルスは soft tick の中で一生生き続けることが出来る)。

\section{ロ）污染した食品の移動の監視}

現状ではアフリカやロシアなどの污染国によるリスクマ ネージメントは必ずしも信頼できるとは言えない。従って 受け入れ国側の検疫を強化し, すべての車両や船舶や航空 機の豚肉製品の持ち込久を禁止する対策に頼るしかない。 これはアフリカのみならずロシアとその周辺の ASF 污染 国にも当てはめられる。そのためには旅行者や調理担当者 や残飯処理関係者に対するリスクコミュニケイションを再
度強化して行くしかない。特に長距離ハイウエイやシべリ ア鉄道周辺に注意を払い, 航空機はアフリカからの直行便 は少ないが，特にロシアや東欧からの直行便に注意が必要 である。ロシアへの旅行業者や旅行者に対するリスクコ ミュ二ケーシオンの再強化も重要である。またこの 1～2 年間で ASF の感染地域がどの位のスピードで拡大するか 監視する必要がある。

\section{7）結論}

ASF に効くワクチンも抗生物質もなく, ASF を撲滅す るには全ての感染豚を殺処分するしかない。豚コレラや口 蹄疫のような安易な病気ではない。いま最も重要なことは, いかにしてアフリカ豚コレラからアジアの養豚産業を守る ことができるかが問題であり，あらゆる対策を研究・強化 しておくことである。中国を含むアジアでは世界の過半数 の豚が飼育されて扔り，ASFがアジア，特に中国や東南 アジアに侵入した場合の被害は計り知れない。従って, こ の病気のアジアへの侵入を未然に防ぐことが，今アジアの 獣医に課せられた最大の課題である。

\section{参考資料}

1）小澤義博, 佐々木正雄: 新版家畜の海外悪性伝染病, チクサン出版社, 187-192，2011.

2) Sanchez-Vizcaino, J.M. et al. : African swine fever : An epidemiologic up-date, Transboundary diseases, 59, 27-35, 2012.

3) Plowright, W. : African swine fever : A retrospectic review, Rev. sci. tech., OIE, 455-468, OIE, 1986.

4) Cogin, A. et al. : African swine fever in the North Caucasus region and Russian Federation in years 2007-2012, Virus Res., 198-203, 2013.

5) Wilkinson, J.P. et al. : African swine fever in Malta, 1978, Vet. Rdc., 106, 94-97, 1980.

6) Rousset, D. et al. : African swine fever introduction into Madagascar, history and lessons from an emergence, Arch. Inst. Pasteur Madagascar, 31 (3), 67, 2001.

7) Roulands, R.J. et al. : African swine fever virus isolate, Georgia, 2007, Emerg. Infect. Dis., 14 (12), 1870-1874, 2008. 